2005. Conservation of the heterodimeric glycoprotein hormone subunit family proteins and the LGR signaling system from nematodes to humans. Endocrine, 26, 267-276.

9 ) Dos Santos S, Bardet C, Bertrand S, Escriva H, Habert D, Querat B, 2009. Distinct expression patterns of glycoprotein hormone-a2 (GPA2) and -b5 (GPB5) in a basal chordate suggest independent developmental functions.
Endocrinology, 150, 3815-3822.

10) Tando Y, Kubokawa K, 2009. Expression of the gene for ancestral glycoprotein hormone beta subunit in the nerve cord of amphioxus. Gen Comp Endocrinol, 62, 329-339.

11) Tando $Y$, Kubokawa K, 2009. A homolog of the vertebrate thyrostimulin glycoprotein hormone a subunit (GPA2) is expressed in amphioxus neurons. Zool Sci, 26, 409-414.

\title{
ニワトリヒナの摂食行動とそのう通過速度に対する ボンベシンとボンベシン様ペプチドの効果
}

\author{
橘
} 哲 也 (愛媛大学・農学部)

E-mail: tetsu@agr.ehime-u.ac.jp

\section{1.はじめに}

ボンベシンはカエルの皮膚から単離され たペプチドである ${ }^{1)}$ 。ボンベシンは哺乳類の 摂食行動を抑制することから ${ }^{2)}$ 、哺乳類にも ボンベシン様ペプチドが存在していることが 示唆されていた。事実、その後の研究により、 ボンベシン様ペプチドとしてニューロメジン B (NMB)、ガストリン放出ペプチドおよびニ ユーロメジン C (NMC) が発見されている ${ }^{3,4)}$ これらのボンベシン様ペプチドを哺乳類に中 枢ならびに末梢投与すると、ボンベシンと同 様に、摂食行動の抑制 2 , 5)、飼料の消化管通 過速度の低下 ${ }^{6)}$ および体温の低下 ${ }^{7)}$ をき起 こす。

ボンベシン様ペプチドはニワトリにおいて も発見されている ${ }^{8)}$ 。ニワトリヒナにボンベ シンを脳室内投与すると摂食行動が抑制され ることから 9 、 、ヒにおけるボンベシンとボ ンベシン様ペプチドの作用は哺乳類と同様と 推察されている。しかしながら、ヒナにおけ るボンベシンおよびボンベシン様ペプチドの 作用は詳細には調べられてはいない。

そこで、本研究ではボンベシンとボンベシ ン様ペプチドがニワトリヒナの損食行動、飼
料の消化管通過率および体温にどのような影 響を与えるかを調べた。なお、本研究で用い たボンベシン様ペプチドはNMBと NMCで ある。

\section{2. 摂食行動に対するボンベシンおよびボン ベシン様ペプチドの効果}

ボンベシン様ペプチドとその受容体がニワ トリの消化管を含む末梢組織と中枢神経系に 存在していることが明らかにされているの で3,4,10〜12)、ボンベシンとボンベシン様ペ プチドを腹腔内および脳室内投与した後の摂 食量の変化を調べた。なお、ボンベシンの脳 室内投与によりヒナの摂食量が低下すること が明らかにされているので9)、本研究では 15 時間絶食させ食欲が増進しているヒナを実験 に供した。

いずれのペプチドでも、高濃度 $(5 \mathrm{nmol})$ で脳室内投与すると摂食量が有意に減少した (図1)。しかし、NMBの摂食抑制効果は他 のペプチドに比べて弱く、かつ短時間で消失 した。同様の摂食抑制作用は腹腔内投与でも 見られたが、ボンベシンが低用量 $(60 \mathrm{nmol} /$ $\mathrm{kg}$ )で見られたのに対し、NMBとNMCの作 


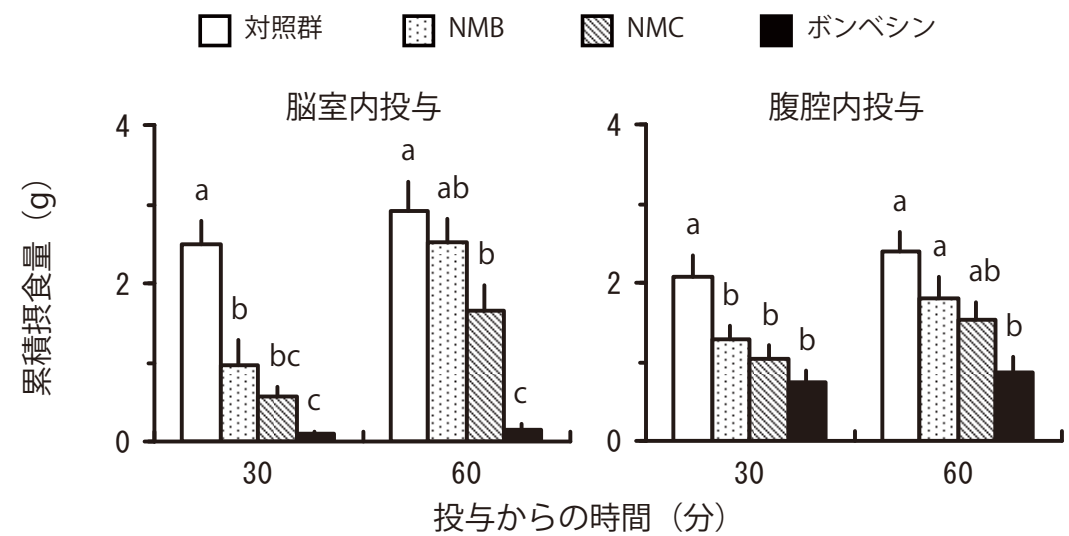

図1ボンベシンおよびボンベシン様ペプチドの投与による摂食量の変化 脳室内投与と腹腔内投与の投与量はそれぞれ $5 \mathrm{nmol}$ と $300 \mathrm{nmol} / \mathrm{kg}$ である。值は平均 值土標準誤差で示す $(\mathrm{n}=8-10)$ 。各時間帯において異符号に有意差あり $(\mathrm{P}<0.05)$ 。 いずれの投与でも全てのペプチドはニワトリヒナの摂食量を減少させた。

用は高用量 $(300 \mathrm{nmol} / \mathrm{kg})$ 投与時にのみ見ら れた(図1)。これらの結果から、中枢と末梢 のボンベシン様ペプチドはヒナの摂食行動の 抑制に関わっていることが示唆された。なお、 脳室内投与と腹腔内投与のいずれにおいても、 摂食抑制効果はボンベシン、NMC、NMB の順に強かった。

\section{3. 飼料の消化管通過速度に対するボンベシ}

\section{ンおよびボンベシン様ペプチドの効果}

ボンベシンおよびボンベシン様ペプチドは 哺乳類の消化管運動に影響を与えることが明 らかにされている6)。そこで、これらのぺプ チドがヒナの飼料の消化管通過率に影響を与 えるかについて調べた。ニワトリの食道には 飼料を一時的に蓄えることができるそ震があ り、そ囊および消化管の残存飼料は絶食によ り大部分が消化、吸収、排泄される。そこで、 15時間絶食させたヒナにボンベシンおよび ボンベシン様ペプチドを脳室内または腹腔内 投与し、その直後にそ囊内に液状飼料を注入 した。1時間後にそ囊を摘出し、残存液状飼 料量を測定して飼料のそ囊通過速度を調べた。

脳室内投与では、いずれのペプチドも 飼料のそ囊通過速度を有意に低下させた が、NMBと NMCはボンベシンよりも比較 的弱い効果を示した (図2)。腹腔内投与した
場合ではNMBには効果が見られなかったが、 NMCとボンベシンはそ震通過速度を有意に 低下させた (図3)。これらの結果から、中枢 ならびに末梢のボンベシン様ペプチドはヒナ の飼料の消化管通過速度を抑制することが明 らかとなった。

\section{4. 体温に対するボンベシンとボンベシン様 ペプチドの作用について}

次いで、ボンベシンおよびボンベシン様ペ プチドがヒナの体温にどのような影響を与え るかを調べた。これらのペプチドは哺乳類の 体温を低下させることが明らかにされている が7）、ナにおいては脳室内、腹腔内投与い ずれの場合においても有意な効果は見られな かった。

\section{5. まとめ}

ボンベシン様ペプチドは、中枢投与ならび に末梢投与のいずれの場合においても、ニワ トリヒナの摂食を抑制し、飼料のそ囊通過速 度を抑制する傾向を示した。これらの結果か ら、ボンベシン様ペプチドの効果は哺乳類と ヒナでよく保存されていると考えられた。し かし、哺乳類では体温低下作用をもつボン心゙ シン様ペプチドがヒナには影響を与えなかっ たことから、その効果の全てが保存されてい 


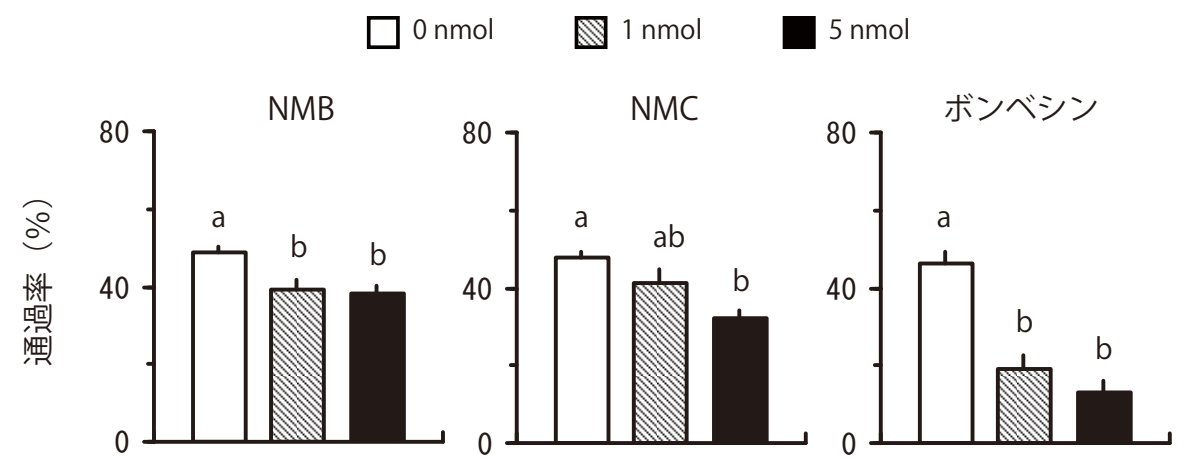

図2 ボンベシンおよびボンベシン様ペプチドの脳室内投与による飼料のそ囊通過率の変化 值は平均值士標準誤差で示す $(\mathrm{n}=9-10)$ 。各ペプチドにおいて異符号に有意差あり $(\mathrm{P}<$ 0.05)。全てのペプチドはニワトリヒナの飼料のそ囊通過速度を低下させた。

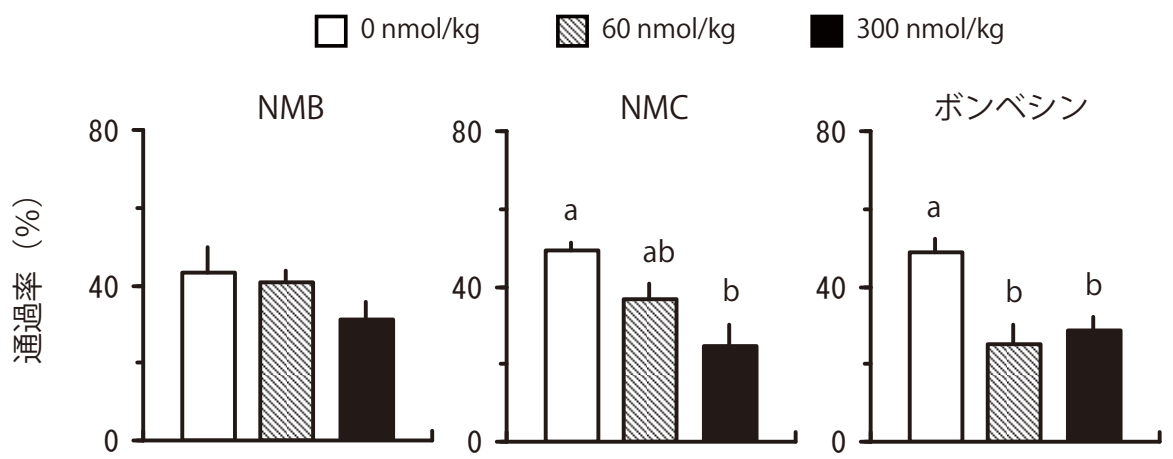

図3 ボンベシンおよびボンベシン様ペプチドの腹腔内投与による飼料のそ囊通過率の変化 值は平均值土標準誤差で示す $(\mathrm{n}=6-9)$ 。各ペプチドにおいて異符号に有意差あり $(\mathrm{P}<0.05)$ 。 NMCとボンベシンはニワトリヒナの飼料のそ囊通過速度を低下させた。

ないことを見出した。

本論文は、Differential thresholds of neuromedins B-, C-, and bombesin-induced anorexia and crop-emptying rate in chicks (Tachibana $\mathrm{T}$, Matsuda K, Sawa H, Mikami A, Ueda H, Cline MA) と 題 L、Gen Comp Endocrinol, (2010) 169, 144-150に発表した。

\section{文 献}

1 ) Anastasi A, Erspamer V, Bucci M, 1971. Isolation and structure of bombesin and alytesin, 2 analogous active peptides from the skin of the European amphibians Bombina and Alytes. Experientia, 27, 166-167.

2 ) Gibbs J, Fauser DJ, Rowe EA, Rolls BJ, Rolls ET, Maddison SP, 1979. Bombesin suppresses feeding in rats. Nature, 282, 208-210.
3 ) Minamino N, Kangawa K, Matsuo H, 1983. Neuromedin B: a novel bombesin-like peptide identified in porcine spinal cord. Biochem Biophys Res Commun, 114, 541-548.

4 ) Minamino N, Kangawa K, Matsuo H, 1984. Neuromedin C: a bombesin-like peptide identified in porcine spinal cord. Biochem Biophys Res Commun, 119, 14-20.

5 ) Gibbs J, Kulkosky PJ, Smith GP, 1981. Effects of peripheral and central bombesin on feeding behavior of rats. Peptides, 2, 179-183.

6 ) Scarpignato C, Bertaccini G, 1981. Bombesin delays gastric emptying in the rat. Digestion, 21, 104-106.

7 ) Brown M, Rivier J, Vale W, 1977. Bombesin: potent effects on thermoregulation in the rat. Science, 196, 998-1000.

8 ) Ohki-Hamazaki H, Iwabuchi M, Maekawa F, 2005. Development and function of bombesin-like peptides and their receptors. Int J Dev Biol, 49, 293-300. 
9 ) Bungo T, Ando R, Kawakami S, Ohgushi A, Shimojo M, Masuda Y, Furuse M, 2000. Central bombesin inhibits food intake and the orexigenic effect of neuropeptide $\mathrm{Y}$ in the neonatal chick. Physiol Behav, 70, 573-576.

10) Namba M, Ghatei MA, Bishop AE, Gibson SJ, Mann DJ, Polak JM, Bloom SR, 1985. Presence of neuromedin B-like immunoreactivity in the brain and gut of rat and guineapig. Peptides, 6, 257-263.
11) Sakamoto A, Kitamura K, Haraguchi Y, Yoshida T, Tanaka K, 1987. Immunoreactive neuromedin $\mathrm{B}$ and neuromedin C: distribution and molecular heterogeneity in rat and human tissue extracts. Am J Gastroenterol, 82, 1035-1041.

12) Hernanz A, 1990. Characterization and distribution of bombesin-like peptides in the rat brain and gastrointestinal tract. Biochem. Cell Biol, 68, 1142-1145.

\title{
CIN85はドーパミン受容体のエンドサイトーシスを 制御しマウスの行動に影響を及ぼす
}

\author{
下 川 哲 昭 (群馬大学大学院 ・医学系研究科 - 応用生理学) \\ E-mail: simokawa@med.gunma-u.ac.jp
}

\section{1.はじめに}

受容体型チロシンキナーゼ (RTKs)の一つ である上皮増殖因子受容体 (EGFR) はEGF と結合後、二量体形成、チロシンリン酸化に 引き続き多様なタンパク質との結合等を介 して生理機能を発現する(図 1)。その後、細 胞内に内部移行し(インターナリゼーショ ン)、エンドゾームを経てリソゾームでの分 解やリサイクル過程に選別される。このうち CIN85 (Cbl-interacting protein of $85 \mathrm{kDa}$ ) は ubiquitin ligaseとして機能する $\mathrm{Cbl}$ と相互作
用を持つ情報伝達の downregulationを担う分 子である。

EGFRが分解に至る過程でCIN85はCblを 介してモノユビキチン化される。モノユビキ チン化はエンドゾームへの sorting signalとし て働く。さらにCblはEGFRをマルチモノユ ビキチン化する。これらは endophilinを含め た膜輸送分子複合体を形成して一緒にエンド ゾームに輸送され分解過程へ移行する ${ }^{1)}$ (図 2)。

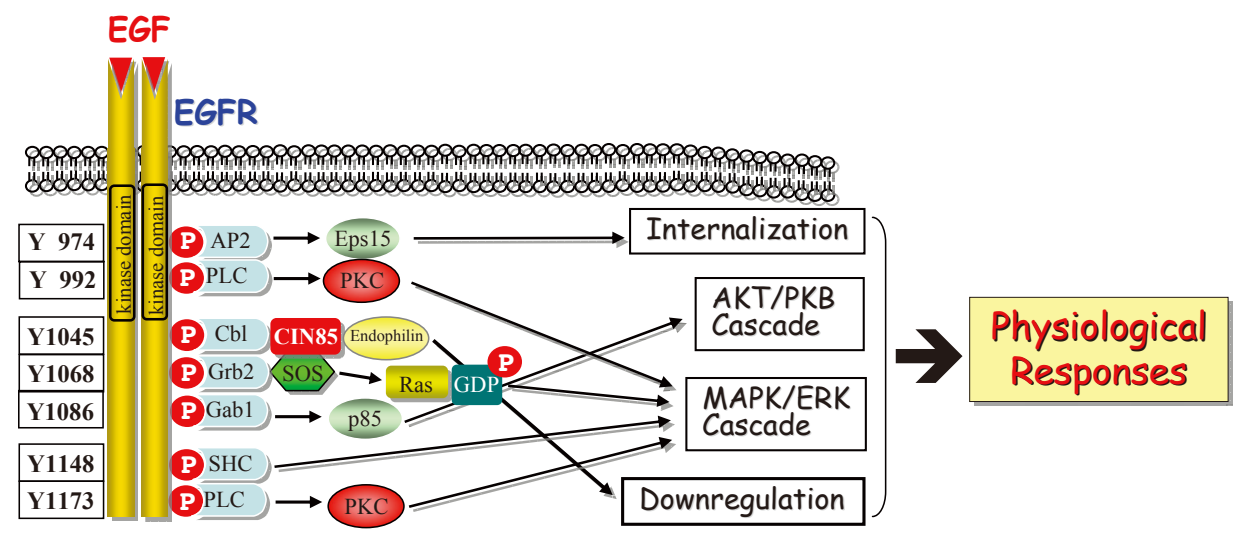

図1 EGFRにおけるリガンド依存性のチロシンリン酸化とシグナル伝達機構 